\title{
U.S. Geological Survey Programs in North Carolina
}

\section{U.S. Department of the Interior - U.S. Geological Survey}

On September 2, 1895, U.S. Geological Survey (USGS) hydrographer Cyrus Babb, with assistance from North Carolina State Geologist Joseph Holmes, established a streamflow-measurement gage on the French Broad River at Asheville (fig. 1). This streamflow gage, which was the first in the South and only the third east of the Mississippi River, has been relocated twice but otherwise has been in continuous operation. The USGS has worked cooperatively for 100 years in North Carolina with Federal, State, and local agencies to provide credible data and unbiased scientific information. In 1995, the USGS operated about 400 streamflow- groundwater- and water-quality-measurement stations in North Carolina. The wide range in

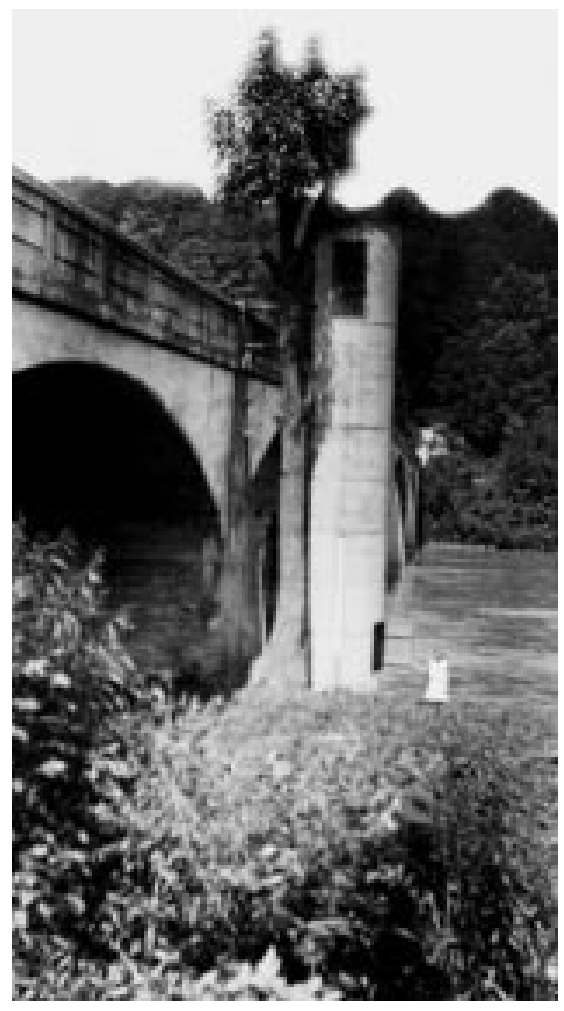

Figure 1. Streamflow-gaging station in nearly continuous operation since 1895 on the French Broad River at Asheville. physiographic and geologic conditions across North Carolina (fig. 2) reflects the diversity of earth science issues in the State. The rocks that underlie the State yield rich soils and metallic and industrial mineral resources. They also provide the framework over and through which the State's water resources flow.

\section{Water-Resources Data Collection}

The 17 major rivers in the State supply drinking water to users in North Carolina and adjoining States. The rivers also are used for commerce, recreation, and wastewater discharge. The USGS, in cooperation with more than 20 Federal, State, and local

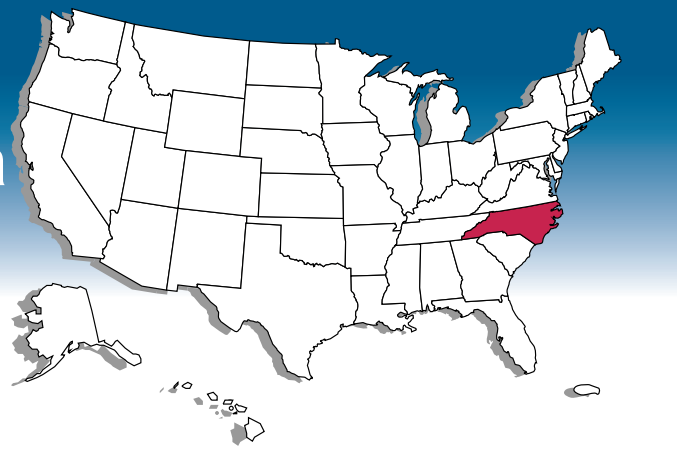

Index of Subjects

Water-Resources Data Collection

Reservoir Water Quality

Metallic and Industrial Mineral-Resource

Assessments

Sea-Floor Mapping off Wrightsville Beach

Coastal Plain Ground-Water Resources

Studies at U.S. Department of Defense Facilities

Topographic Mapping

Earth Science Information

Geologic Mapping

Estuarine Circulation and Water-Borne

Material Transport

National Water-Quality Assessment Program

agencies, collects continuous streamflow records at about 183 sites across the State. Intermittent measurements of streamflow are made at about 70 sites in support of the

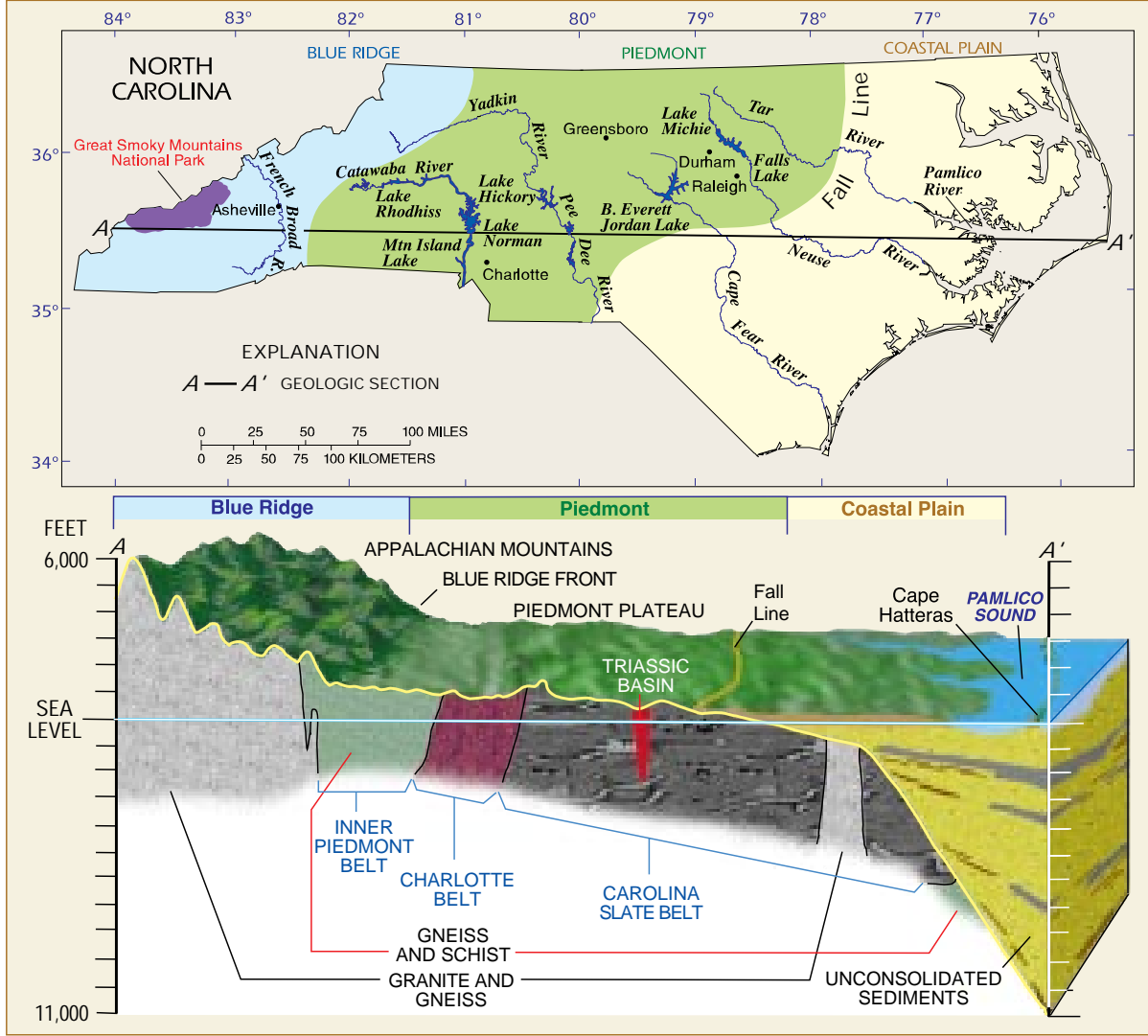

Figure 2. Map of North Carolina and diagrammatic geologic section of the State. 
State's water-quality management program. The USGS also collects water-quality data at more than 60 stream and lake sites. These data are required for daily and longterm management of the State's surfacewater resources, determining the extent and severity of droughts, characterizing and predicting conditions during floods, and monitoring and interpreting the effects of human activities on streamflow and water quality.

More than one-half of North Carolina's population relies on ground water for water supply. The USGS collects and publishes ground-water data collected from about 115 wells across the State. These data are needed to determine the effects of human stresses, climate, topography, and geology on ground-water storage.

\section{Reservoir Water Quality}

Reservoirs supply drinking water to about one-third of the State's residents and also provide valuable recreational opportunities and habitat for wildlife. The USGS

provides scientific information to a number of State and local agencies that are responsible for protecting the water quality of these important resources.

Eroded sediment from watersheds often accumulates in water-supply reservoirs and lessens their storage capacity. USGS studies indicate that sedimentation has reduced the storage volume of Lake Michie, near Durham, by more than 20 percent between 1926 and 1992. Long-term monitoring by the USGS indicates that the amount of sediment transported from land to surface waters differs geographically across the State. The highest amounts are in the Yadkin-Pee Dee, the Catawba, and the upper Cape Fear River Basins-all located in the heavily populated Piedmont region.

The USGS, in cooperation with the Triangle Area Water-Supply Monitoring Steering Committee, continues to investigate water quality in Falls and Jordan Lakes and in six smaller reservoirs nearby. Falls and Jordan Lakes supply drinking water to about 500,000 people in the RaleighDurham area. Intensive sampling for suspended sediment, nutrients, metals, organic pollutants, and the pathogens Cryptosporidium and Giardia keeps managers informed of conditions that could threaten public health and use of the reservoirs.
The Catawba River and its reservoirs supply drinking water and hydroelectric power to the Hickory and Charlotte metropolitan areas. The USGS, in cooperation with several local government agencies, is investigating water quality in three of these reservoirs-Rhodhiss Lake, Lake Hickory, and Mountain Island Lake. The studies use detailed computer models to simulate the movement of contaminants and provide alternatives for management of water quality.

\section{Metallic and Industrial Mineral-Resource Assessments}

North Carolina is an important producer of industrial minerals including lithium, mica, feldspar, phosphate, pyrophyllite, and clays for brick manufacture. Supplies of sand, gravel and stone for aggregate are available for infrastructure repair and construction. Although metallic minerals are not mined at present, the State contains reserves of gold, copper, lead, zinc, silver, titanium, zirconium, tin and tungsten. Competition for land, water, and biological resources is affecting the local availability of clay, limestone, sand and gravel, building stone, slate, and other industrial minerals.

The USGS, in cooperation with the North Carolina Geological Survey (NCGS), is preparing an inventory of known metallic and industrial mineral resources. By using geological, geophysical, and geochemical studies, the USGS also is preparing an assessment of potential undiscovered mineral resources in the State. This information can assist Federal and State land-management agencies, regional planners, industry, and local governments in ensuring sound management and use of the State's substantial mineral resources.

\section{Sea-Floor Mapping off Wrightsville Beach}

The USGS, in cooperation with Duke University, is conducting a sand-transport study off Wrightsville Beach-the site of a beach replenishment program for the last 30 years. Information on the movement of sand in the nearshore area is used by coastal engineers to develop and carry out strategies to protect and nourish beaches.
During storms and the post-storm recoveries of a beach, large quantities of sand are moved offshore and back onshore. A sidescan sonar survey and sediment cores collected off Wrightsville Beach show that sediment is transported from the beach to the inner shelf (fig. 3). Gravelly shell hash from the beachface, where it was placed as an artificial replenishment, was detected offshore. This provides direct evidence of net offshore sediment transport. These findings suggest that the beaches and the offshore region must be treated as a single system to understand the transport of sand in the nearshore and to evaluate erosionmitigation measures.

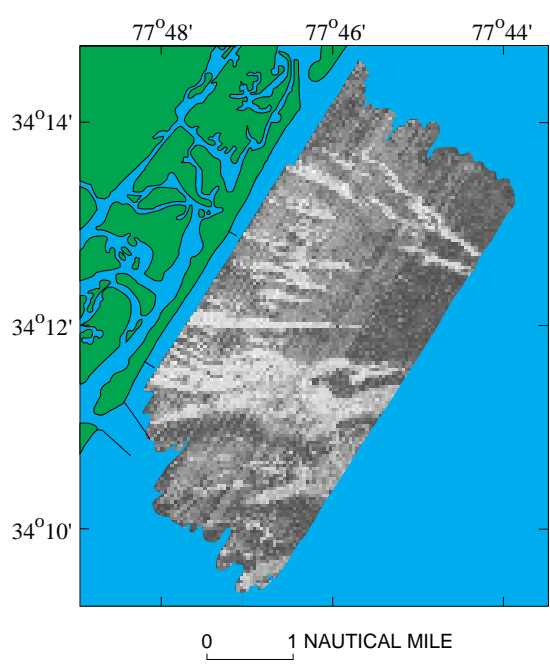

Figure 3. Sidescan sonar mosaic of the area offshore of Wrightsville Beach. Dark tones on the image represent areas of finer grained sediments; light tones represent areas of coarser grained sediments

\section{Coastal Plain Ground-Water Resources}

The USGS conducts regional groundwater studies to define aquifers, map water levels, develop regional aquifer simulation models, and develop local ground-water flow models. Ground-water levels in many areas of the Coastal Plain are declining because of heavy pumping. For example, USGS studies indicate that the groundwater levels in the upper Cape Fear aquifer in parts of Bladen County have declined 90 feet (fig. 4); elsewhere in the Coastal Plain, water levels have declined nearly 150 feet since the early 1900's. These studies are used by the North Carolina Division of Water Resources and by numerous local governments to manage ground-water supplies in the Coastal Plain. 


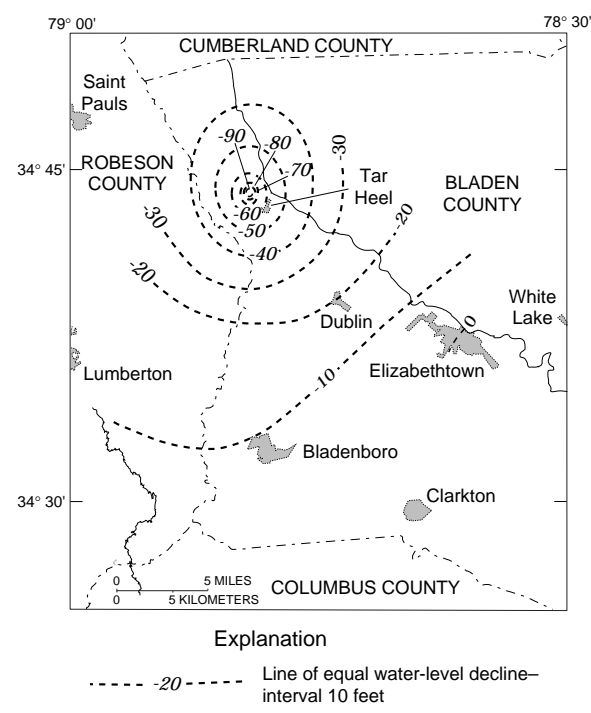

Figure 4. Ground-water-level decline in the upper Cape Fear aquifer of the southern Coastal Plain between fall of 1992 and fall of 1994.

\section{Studies at U.S. Department of Defense Facilities}

Several U.S. Department of Defense sites in North Carolina have some level of contamination caused by past production, storage, or use of fuels, chemical agents and munitions. Since the mid-1980's, the USGS has been collecting hydrologic data and conducting investigative studies at Fort Bragg, Camp Lejeune, and the Cherry Point Marine Corps Air Station (fig. 5). Goals of the studies include characterizing regional and site hydrogeology, defining the extent of soil and ground-water contamination, determining contaminant transport pathways, and predicting the fate of contaminants. Innovative techniques for site characterization, chemical detection, and biological remediation have been developed and tested as part of these studies. The USGS monitors the progress of

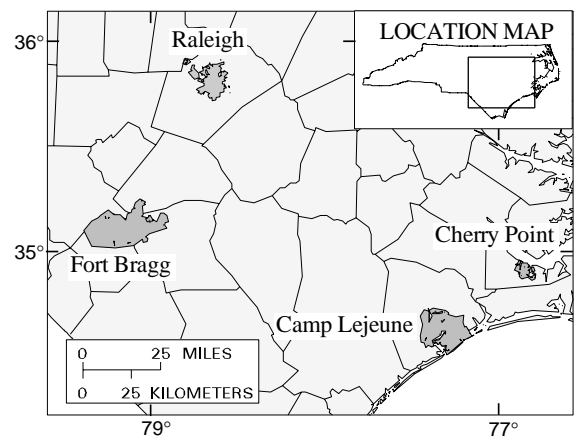

Figure 5. U.S. Department of Defense facilities near Raleigh. implemented remedial actions and applies knowledge gained from one site to another.

\section{Topographic Mapping}

North Carolina's topography is illustrated by 962 topographic maps at a scale of 1:24,000 ( 1 inch equals 2,000 feet). These maps depict basic natural and cultural features of the landscape, such as lakes and streams, highways and railroads, boundaries, and geographic names. Contour lines are used to depict the elevation and shape of terrain. These maps are among the most popular and versatile products of the USGS and are useful for civil engineering, land-use planning, naturalresource monitoring, and other technical applications. The USGS, in cooperation with the NCGS, has photorevised 10 percent of the State's 1:24,000-scale topographic maps near Salisbury and Reidsville. In addition, several layers of information on the printed maps are being converted to digital (computer-readable) files. Political boundaries, water features, and transportation features are available as digital line-graph files for about 90 percent of the maps in the North Carolina series. Elevation data are available for about 80 percent of the State in a digital elevationmodel format. The USGS has a worksharing agreement with the North Carolina Center for Geographic Information and Analysis (CGIA) to produce digital data at the 1:24,000 scale for two-thirds of the State.

A digital orthophoto quarter-quadrangle (DOQ) is derived from digital aerial photographs that combine the image characteristics of a photograph with the scale accuracies of a map, and can be a component in geographic information systems. The pixel resolution of a DOQ is 1 to 3 meters. The USGS, in collaboration with the NCGS, the North Carolina Department of Transportation, and the CGIA, is producing DOQ's for the eastern and central portions of the State using 1993 leaf-off black and white photography. This statewide program is coordinated through the State Mapping Advisory Committee, which is a component of the Geographic Information Coordinating Council that was established by the Governor. Twenty-eight percent of the DOQ's for the State are complete (October 1996). Matching State and Federal funds have been identified to complete the State DOQ coverage. The
USGS and the CGIA, in cooperation with the South Carolina Department of Natural Resources, are preparing color infrared DOQ's along the North Carolina-South Carolina border.

\section{Earth Science Information}

The USGS, in cooperation with the NCGS, has Earth Science Information Centers (ESIC's) in the NCGS offices in Raleigh and Asheville. As part of the national ESIC network, these offices provide computer-based searches for information regarding paper maps, digital and remotely sensed data, and other Earth science information. Data to ESIC offices are updated annually.

\section{Geologic Mapping}

At the request of the National Park Service, the USGS is conducting bedrock, surficial, and geochemical studies in a 250square-mile area of the Great Smoky Mountains National Park. Results of the studies will become part of a new computerized data base for use in improving management of the Nation's most visited National Park.

The STATEMAP component of the National Geologic Mapping Program (NGMP) provides funds to the NCGS for geologic mapping near Asheville and Raleigh. Through EDMAP, another component of the NGMP, funding is provided to train new field geologists. Geologic maps are essential for addressing many geologic-related problems, such as land use and infrastructure planning, mineral resource identification, and environmental assessment and planning.

\section{Estuarine Circulation and Water-Borne Material Transport}

The determination of circulation patterns and rates of movement of waterborne materials in estuaries typically requires specialized hydrographic data collection and the development of complex computer models. Information on flow and transport is needed to allocate wasteloads from point and nonpoint sources for protection of water quality, to interpret water-quality and biological data, and to predict rates of movement and 
dilution of spilled or released substances. The USGS, in cooperation with the North Carolina Department of Environment, Health and Natural Resources, has developed flow and transport models for segments of the Roanoke, the Pamlico (fig. 6), and the Neuse River estuaries. These models can be applicable in the management of water quality and the protection of aquatic habitat.

\section{National Water-Quality Assessment Program}

To provide information on the water quality of the Nation's water resources, the USGS has implemented the National Water-Quality Assessment (NAWQA) Program through a series of study units that encompass major drainage basins and population centers. The goals of the NAWQA Program are to describe current water-quality conditions, define longterm trends in water quality, and provide an understanding of the natural and human factors that affect water quality. Results from the NAWQA Program studies provide policymakers, resource managers, and the public with an improved scientific basis from which to evaluate water-quality-management programs.

Parts of three NAWQA Program study units are located in North Carolina (fig. 7). The Albemarle-Pamlico drainage study began in 1991 and focuses on evaluating the effects of land use on surfaceand ground-water quality. More than 80

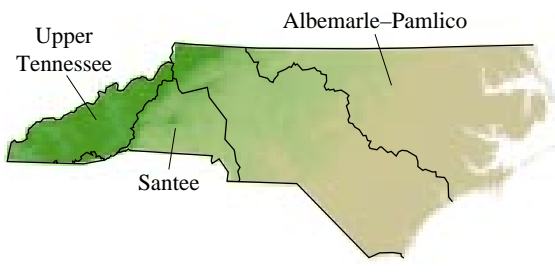

Figure 7. National Water-Quality Assessment Program study units in North Carolina.

wells and 100 surface-water sites have been sampled for organic and inorganic chemicals (fig. 8). Data collection for the Upper Tennessee and the Santee studies began in 1995 .

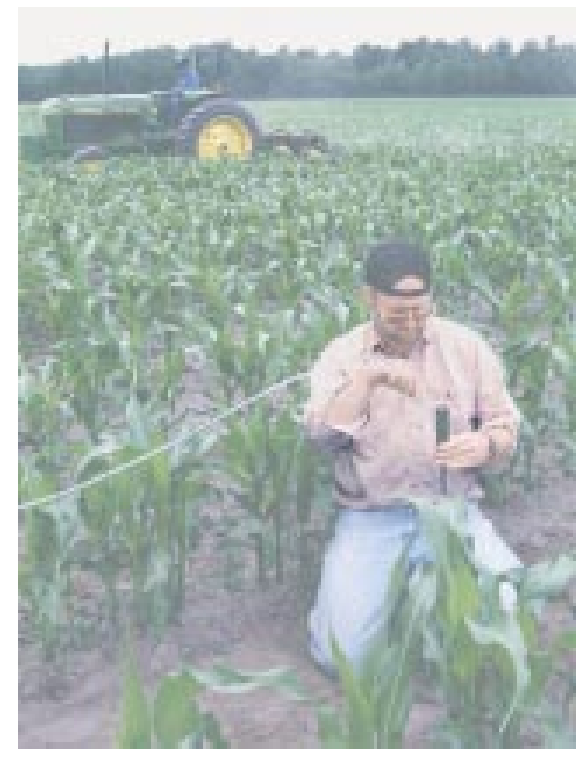

Figure 8. Sampling shallow ground-water for nutrients and pesticides.
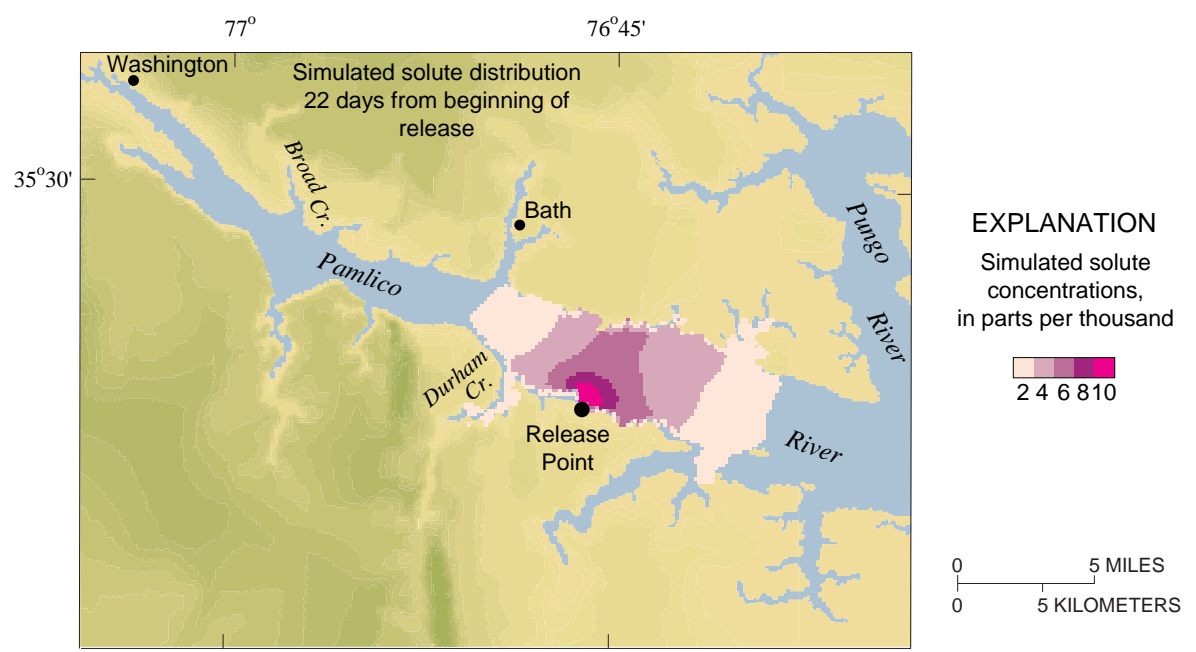

Figure 6. Simulated solute-concentration distribution resulting from actual tidal and wind conditions and a hypothetical release of 25 million gallons per day and an initial strength of 100 percent concentration.

USGS State representative 3916 Sunset Ridge Road Raleigh, NC 27607

(919) $571-4000$

Fax: (919) 571-4041

Email: dc_nc@usgs.gov Home Page URL http://wwwnc.usgs.gov/

Additional earth science information can be found by accessing the USGS Home Page

on the World Wide Web at

http://www.usgs.gov/

For more information on all USGS reports and products (including maps, images, and computerized data), call

1-800-USA-MAPS

The USGS provides maps, reports, and information to help others meet their needs to manage, develop, and protect America's water, energy, mineral, biological, and land resources. We help find the natural resources needed to build tomorrow and supply the scientific understanding needed to help minimize or mitigate the effects of natural hazards and environmental damage caused by natural and human activities. The results of our efforts touch the daily life of almost every American. Fact Sheet FS-033-96 